\section{Inflammatory and non-inflammatory triggers of acute coronary syndromes}

Inflammation plays an important role in the pathogenesis of acute coronary syndromes (ACS). ${ }^{1}$ However, ACS include different clinical conditions that can present as an acute cardiac event, and it may also be seen in various clinical settings independent of underlying cardiovascular status and traditional risk factors. ${ }^{2}$ Recently, Westerlind et $a l^{3}$ reported that siblings of patients with rheumatoid arthritis (RA) are at increased risk of ACS that could not be explained by traditional cardiovascular risk factors. This article provides excellent information regarding importance of inflammation and its hereditary role in the pathophysiology of ACS. Nevertheless, because of many clinical conditions may be the underlying cause of ACS and myocardial infarction (MI), there are some important points to be discussed to clarify the findings of the present article.

ACS and MI may also occur as an acute cardiac event in the absence of significant coronary artery disease (CAD) and inflammation. This type of $\mathrm{MI}$ is known as type $2 \mathrm{MI}$, and may occur in the context of a mismatch between myocardial oxygen supply and demand due to various diseases. ${ }^{4}$ Therefore, ACS is not only triggered by atherosclerotic plaque disruption, it may occur due to non-cardiovascular reasons, and this situation should be taken into consideration while defining ACS. Additionally, inflammation also seems to play a role in the mechanism of ACS secondary to non-atherosclerotic spontaneous coronary artery dissection. ${ }^{5}$ Hence, it would be worth to know the CAD severity and the underlying mechanism of ACS of the study groups in the study by Westerlind et $a l,{ }^{3}$ to comment on the relationship between index event and patients' clinical conditions.

In conclusion, rheumatoid diseases and inflammation have important roles in the pathophysiology of CAD and ACS. However, ACS and MI do not occur only due to atherosclerotic plaque disruption. Non-cardiovascular and non-atherosclerotic reasons also may trigger ACS and MI in various clinical conditions. Hence, the underlying mechanism of ACS should be clearly stated to claim a relationship between siblings of patients with RA and an increased risk of ACS.

Mehmet Eyuboglu $\odot$
Correspondence to Dr Mehmet Eyuboglu, Cardiology, Bergama State Hospital, Izmir 35000, Turkey; mhmtybg|@gmail.com

Handling editor Josef S Smolen

Contributors I am the sole author.

Funding The authors have not declared a specific grant for this research from any funding agency in the public, commercial or not-for-profit sectors.

Competing interests None declared.

Patient consent for publication Not required.

Provenance and peer review Not commissioned; internally peer reviewed.

(c) Author(s) (or their employer(s)) 2020. No commercial re-use. See rights and permissions. Published by BMJ.

$$
\text { A) Check for updates }
$$

To cite Eyuboglu M. Ann Rheum Dis 2020;79:e49.

Received 24 February 2019

Accepted 25 February 2019

Published Online First 6 March 2019

\section{SLinked}

http://dx.doi.org/10.1136/annrheumdis-2019-215293

Ann Rheum Dis 2020;79:e49. doi:10.1136/annrheumdis-2019-215277

\section{ORCID iD}

Mehmet Eyuboglu http://orcid.org/0000-0002-5754-9382

\section{REFERENCES}

1 Mulvihill NT, Foley JB. Inflammation in acute coronary syndromes. Heart 2002:87:201-4.

2 Roffi M, Patrono C, Collet JP, et al. ESC guidelines for the management of acute coronary syndromes in patients presenting without persistent ST-segment elevation: Task Force for the management of acute coronary syndromes in patients presenting without persistent ST-segment elevation of the European Society of cardiology (ESC). Eur Heart J 2015;2016:267-315.

3 Westerlind H, Holmqvist M, Ljung L, et al. Siblings of patients with rheumatoid arthritis are at increased risk of acute coronary syndrome. Ann Rheum Dis 2019;78:683-7.

4 Thygesen K, Alpert JS, Jaffe AS, et al. Fourth universal definition of myocardial infarction (2018). Eur Heart J 2019;40:237-69.

5 Canga Y, Guvenc TS, Calik AN, et al. Systemic inflammatory activation in patients with acute coronary syndrome secondary to nonatherosclerotic spontaneous coronary artery dissection. North Clin Istanb 2018;5:186-94. 